\title{
Articles
}

\section{The Carles Puigdemont Case: Europe's Criminal Law in the Crisis of Confidence}

\author{
By Dr. Stefan Braum*
}

\begin{abstract}
The case of Carles Puigdemont underlines that European criminal law is in a crisis of confidence. The Higher Regional Court of Schleswig-Holstein has rejected a Spanish European arrest warrant for the criminal offence of rebellion because it lacks double criminality. It applied German law de lege artis without, however, questioning the European legal framework. The case would have provided an opportunity to refer the matter to the European Court of Justice for a preliminary ruling in order to further specify the European law criteria of double criminality. This would have been the adequate legal response to a politically explosive case. In the end, the Spanish judiciary sees itself disavowed and the system of the European arrest warrant called into question.
\end{abstract}

* Professor at University of Luxembourg, faculty of Law, Economics, and Finance. 


\section{A. Europe's Criminal Law in the Crisis of Confidence}

On March 21, 2018, the Spanish judiciary issued a European arrest warrant against the President of the Catalan Regional Government, Carles Puigdemont. The Spanish authorities asked him to be persecuted and extradited for both rebellion and corruption in the form of embezzlement of public funds-embezzlement. The allegations are based on Mr. Puigdemont's activities in the long-standing conflict between Catalonia and the Spanish central government over the independence of Catalonia. Among other things, the persecuted allegedly called for a referendum on Catalonia's independence, even though this had previously been rejected as illegal by the Spanish Constitutional Court. For the execution of the referendum Mr. Puigedmont pursued for choice materials, choice documents, and other activities incurring costs at a value of 1.6 million euro. During the referendum, Puigdemont had to reckon with violent clashes and the associated injury of Spanish police officers.

Mr. Puigdemont was provisionally arrested on German soil on March 25, 2018-after crossing the border from Denmark to Germany-and placed in police custody. At the request of the Public Prosecutor's Office of Schleswig-Holstein, the First Senate of the Higher Regional Court of Schleswig-Holstein decided on April 5, 2018, to order the arrest for extradition against the person prosecuted, but at the same time to suspend the detention for extradition subject to conditions. ${ }^{1}$ The Higher Regional Court rejected extradition as inadmissible from the outset because of the criminal offense of the "rebellion." Here it is missing the condition of the double criminality, because it lacks considering the analogous conversion of the facts with regard to the then relevant criminal offense of high treason in the German Penal Code Book- $\S 81 \mathrm{StGB}$-at the constituent element of "force." With regard to the accusation of corruption-in the form of embezzlement-the Senate has asked for additional information in order to be able to more closely examine the admissibility of extradition with regard to this offense. On May 22,2018 , the Senate once again rejected motions by the Attorney General of the State of Schleswig-Holstein to rewrite the extradition warrant and order the execution of extradition custody. ${ }^{2}$

New evidence presented could not shake the Senate in its legal opinion. Nor was the supplementary offense of breach of the peace $-\S 125$ StGB - relevant for lack of individual imputability of an offense.

${ }^{1}$ Schleswig-Holsteinisches Oberlandesgericht [HansOLG] [Higher Regional Court] Apr. 5, 2018, 1 Ausl (A) 18/18 (20/18), 2018 (Ger.).

2 Schleswig-Holsteinisches Oberlandesgericht [HansOLG] [Higher Regional Court] May 22, 2018, 1 Ausl (A) 18/18 (20/18), 2018 (Ger.). 
The Schleswig Higher Regional Court is not alone in rejecting the European arrest warrant for Carles Puigdemont. The Belgian judicial authorities have also failed to comply with Spain's request-in part for formal reasons - and refused to extradite former Ministers of the Government of Catalonia. In Germany, the provisional release of Puigdemont has been met with a positive response. On the one hand, Puigdemont-accused by the Spanish judicial authorities-presents himself as a freedom fighter in the German and European media. On the other hand, the Spanish Supreme Court-after an initially cautious reaction-criticized the decision of the Schleswig Higher Regional Court as inappropriate to the problems of the Catalonian attempts at secession. A situation of legal and political anxiety arises. This anxiety is hardly registered in the German judiciary and in public, but all the more so in other Member States: The European arrest warrant-founded as a legal instrument of the European Union and the supposed core of the European area of freedom, security, and justice-is in a power-political context, in contrast to which European criminal law appears to be fragile. The arrest warrant works in motor vehicle theft, but when it comes to political macro-crime, it doesn't work. The reactions of German and other judicial authorities to the Spanish extradition request-the request of a democratic constitutional state-demonstrates: Criminal law in Europe reflects a crisis of confidence between the Member States of the European Union-a crisis resulting from the loss of common legal principles.

With huge matters, of course, the Higher Regional Court examines the German legal situation according to the law on international legal assistance- $§ 79 \mathrm{ff}$. IRG. The political anxiety of the case is subsumed away with the routines of national law. Ultimately, however, we are faced with a European legal problem that goes beyond this national routine and can only be solved in a legally appropriate manner if the arguments put forward in the Carles Puigdemont case-in particular the case law of the European Court of Justice on the EU Framework Decision 2002/584, the principle of mutual recognition under European law, and in particular the requirement of double criminality-are sufficiently processed. In the end, this may reveal the loss of European criminal law principles, but at the same time it also offers the opportunity to constitute the principles of European criminal law in its power-critical function. For European legal problems there are European courts. The Schleswig Higher Regional Court must refer the case to the Court of Justice of the European Union by means of the preliminary ruling procedure.

\section{B. Routines of State Criminal Law}

A European arrest warrant is a European legal instrument applied between judicial authorities of EU Member States. The State issuing an arrest warrant may require that it be enforced in any other EU State. The prerequisite is that states trust each other. It is assumed that the same legal benchmarks apply. The European arrest warrant draws up a catalogue of offenses in which trust goes very far: It will then no longer be examined whether conduct under the law of the requested state is also punishable. For other crimes not listed in the catalogue, the routines of state criminal law seem to apply. 
According to German law-following § 15, paragraph 1 of the Law on International Mutual Legal Assistance in Criminal Matters (IRG) - a person must be ordered into extradition custody upon presentation of an international or European arrest warrant, unless this is inadmissible from the outset- $\S 15$ paragraph 2 IRG. In the case of a European arrest warrant, the special provisions of $\S \S 79 \mathrm{ff}$. IRG. claim validity. This applies in particular to the requirement of double criminality, which does not apply if the European arrest warrant relates to one of the catalogue acts mentioned in EU Framework Decision 2002/584. This is not the case with regard to the accusation of "rebellion."

Therefore, the granting of extradition and the admissibility of extradition detention presuppose double criminality under Spanish and German criminal law. In accordance with the Law on International Mutual Legal Assistance- $\$ 3$ Paragraph 1 IRG)-this depends on the conversion of the facts. The object of the-hypothetical-examination is an unlawful act in the sense of criminal procedure. ${ }^{3}$ The subject of the investigation is whether the facts mentioned in the extradition request would be subject to a criminal penalty under German criminal law. For this purpose, the facts of life stated by the requesting state must be thought of as if they had occurred on German territory. ${ }^{4}$

Against this background, the Schleswig-Holstein Higher Regional Court is therefore rightly examining whether the facts on which the Spanish courts base the offense of rebellion would be subject to a criminal penalty on German territory in accordance with the legal benchmarks of German criminal law- $-\S 1$ StGB. To this end, it relies on a case decided by the Federal Court of Justice-Bundesgerichtshof-with similar facts. In this case, the violent clashes during the demonstrations against the west runway of Frankfurt Airport were the subject of accusations of coercion by constitutional bodies. For the Spanish Supreme Court-but not only for the Supreme Court-it is irritating to observe how an act of state political importance declared unconstitutional in Spain is minimized before a German court-as it were-as a routine of state protection criminal law. The facts of the case to be compared may also determine the hypothetical examination of double criminality, because it sets different premises for the interpretation of the respective facts: The subject of the Federal Court's ruling ${ }^{5}$ was the interpretation of the concept of violence and its definition in relation to the offenses of freedom-such as coercion-which is more restrictive. ${ }^{6}$ Accordingly, the constituent element of the offense of violence in the sense of

\footnotetext{
3 See Michael Kubiciel, ReChtShilferecht in Strafsachen 168 (Kai Ambos et al. eds., 2015); see also Wolfgang SCHOMBURG \& OtTO LAGODNY, INTERNATIONALE RECHTSHILFE IN STRAFSACHEN (5th eds. 2012).

${ }^{4}$ KUBICIEL, supra note 3; and SCHOMBURG, supra note 3.

5 See Bundesgerichtshof [BGH] [Federal Court of Justice], 32 ENTSCHEIDUNGEN DES BUNDESGERICHTSHOFES IN StRAFSACHEN [BGHSt] 170; see also StRAfGesetzBuCH [StGB] [PenAL CODE], $\S 81$, https://www.gesetze-iminternet.de/englisch_stgb/englisch_stgb.html (Ger.).

${ }^{6}$ See StRAFGESETZBUCH, supra note 5.
} 
the offense of treason does not satisfy any physical coercion connected with coercive means. Rather, it is necessary that the pressure thereby exerted on the constitutional body appears appropriate to bend the will of the constitutional body, taking into account all the circumstances which characterize coercion. ${ }^{7}$ The obstacle to the acceptance of coercive success is all the higher in the context of high treason, because the particular prudence and reason of the constitutional bodies must be taken as a starting point in order to be able to withstand political pressure. ${ }^{8}$

These high demands on the vis compulsiva-which was put forward in the context of high treason-do not appear to be necessary in Spanish criminal law. According to the facts stated in the extradition request, it is therefore sufficient to assume the facts of the rebellion that the person persecuted has at least accepted the violence perpetrated against police officers and considered it probable. The Higher Regional Court therefore also states that the "acts of violence that took place on election day" are in any case attributable to the person persecuted. ${ }^{9}$ Consequently, it is not entirely lacking in the characteristic of violence, but in its intensity, which is actually necessary. Ultimately, the Higher Regional Court makes double criminality fail because-according to the legal benchmark of German criminal law-a stricter, more restrictive concept of violence than Spanish criminal law presupposes for the offense of rebellion must be applied to the offense of high treason.

\section{Disruptive European Law}

Nevertheless, it is possible that this inadmissibility of extradition detention under the exclusive legal benchmark of German criminal law either does not hold up under European law or-in view of the procedural context of a European arrest warrant-would at least have to be supplemented by European law. In view of the special nature of the provisions on extradition within the framework of a European arrest warrant, and in the case of a request by another member state of the European Union, it is particularly worth considering whether the traditional part of double criminality under international lawand under $\S 3 \mathrm{IRG}$-is also superimposed by European provisions and their interpretation by the Court of Justice of the European Union in such a way that German criminal law is either not the sole legal benchmark of an extradition permit or at least this benchmark would have to be adapted to European rules.

German law on mutual legal assistance gives priority to the rules on extradition and enforcement between the Member States of the European Union over traditional-

\footnotetext{
${ }^{7}$ See STRAFGESETZBUCH, supra note 5, at § 105.

${ }^{8}$ See id.

${ }^{9}$ See Schleswig-Holsteinisches Oberlandesgericht, supra note 1, at 11.
} 
bilateral-rules between sovereign states. This priority has its principle legitimacy in the mutual recognition of judicial decisions, which is seen as being at the heart of the area of freedom, security, and justice in the European Union and judicial cooperation between its Member States. The principle is supported by the mutual trust of EU Member States in the functioning of the democratic constitutional state, in particular in the protection of fundamental rights and in the independence and impartiality of the judiciary power. In the context of requests for mutual assistance between Member States of the European Union, the principle of double criminality is considered an exception to the principle of mutual recognition-an exception to be interpreted restrictively. ${ }^{10}$

Against this background, the Court of Justice of the European Union interprets the criteria of double criminality. It is questionable whether these criteria support the interpretation of the Higher Regional Court of Schleswig-Holstein, or whether they could rather require supplementary legal considerations, or even oppose the interpretation of the Higher Regional Court. This concerns, above all, the condition of the analogous conversion of the circumstances and the subsequent complete and comprehensive examination of the constituent element of violence after $\S 81$ StGB. Article 2 paragraph 4 of the EU Framework Decision 2002/584 allows-apart from the above-mentioned catalogue actsthe possibility of examining double criminality. This examination must be carried out irrespective of the facts of the case and the designation of the offense.

According to the case-law of the Court of Justice of the European Union, it is a necessary and sufficient condition that the acts underlying the offense in the issuing State also constitute an offense in the executing State. An identity of the offenses in the two Member States concerned is not necessary. ${ }^{11}$ Accordingly, there is no need for the exact match between the constituent elements of the offense as laid down in the law of the issuing and executing Member States, or the designation or classification of these offenses according to the respective national legal systems. ${ }^{12}$ It is therefore harmless that the facts of the case-as communicated by the Spanish judicial authorities-correspond in Spain to the offense of rebellion and in Germany to that of treason. The relevant criterion is rather the correspondence between the elements of the facts on which the offense is based-as reflected in the judgment issued in the issuing State-and the definition of the offense under the law of the executing State. ${ }^{13}$ Thus, the approach of the Higher Regional Court of Schleswig-Holstein, which-like the prevailing opinion in German mutual legal assistance

\footnotetext{
${ }^{10}$ See Case C-289/15, Comm'n v. Grundza, 2017 E.C.R. I-622, para. 41 \& 46; see also Joined Cases C-404/15 \& C659/15, Comm'n v. Aranyosi, Comm'n v. Caldararu, 2016 E.C.R. I-198, para. 77f; see also Case C-579/15, Comm'n v. Poplawski, 2017 E.C.R. I-503, para. 29 f.

${ }^{11}$ See Case C-289/15 supra note 10, at para. 34.

12 Id. para. 35.

${ }^{13} / d$. para. 36.
} 
law-assumes a procedural act that is to be assessed completely by hypothetical examination in accordance with the premises of German criminal law, and also seems supported by the more recent case-law of the Court of Justice of the European Union.

This is, however, only superficially so: For example, the Court of Justice of the European Union requires the competent authority of the executing State to take a flexible approach in the examination of double criminality with the aim of complying as much as possible with the extradition request. ${ }^{14}$ This jurisprudence indicates that the equivalence of factual characteristics and criminal offenses in the executing State does not mean a fully comprehensive normative interpretation of factual characteristics and their possibly conflicting dogmatic interpretation, but rather allows a general agreement to suffice with regard to the factually constituted injustice. Thus, the Court of Justice of the European Union merely requires that the facts of the case be subject to a criminal penalty per se in the executing State. ${ }^{15}$ Implicitly, the European Court of Justice deviates from the criminal procedural dogma of the offense and considers the character of double criminality as an exception to mutual recognition. According to this, only a "relatively high level of abstraction" of the relevant offenses is recorded. ${ }^{16}$ Thereafter, "a perfect match between the taxonomy used to describe that relevant offence" is not required. ${ }^{17}$ Thus, the application of a criminal law-for example, the dogmatic interpretation in the requesting Member State-could have to be recognized in the executing State, even if its application and interpretation would lead to a different result in the executing State. ${ }^{18}$

In view of this penetration of double criminality under European law and the analogous conversion of the facts of the case, the approach of the Higher Regional Court-and of German mutual legal assistance law as a whole-could prove to be excessive in its requirements. Instead of a complete examination of the facts under the benchmark of German criminal law, it would only be important that the offenses of rebellion and high treason are similar in their unjust content. The Higher Regional Court's finding that the person persecuted must take the violence into account during the referendum could constitute a sufficient condition for the requirements of European law for double criminality. Nevertheless, it would be irrelevant for the admissibility of extradition custody-and the possible later granting of extradition-that German criminal law has a more restrictive dogmatic approach with regard to the constituent element of violence

\footnotetext{
${ }^{14}$ Id. para. 36.

${ }^{15} / d$. para. 38.

${ }^{16}$ Id. para. 76 (for the Opinion of Advocate General Michal Bobek on July 28, 2016).

17 Id. para. 77.

${ }^{18}$ See Case C-367/16, Comm'n v. Piotrowski, 2018 E.C.R. I-27, para. 52 (It should be noted, however, that this judgment in turn is in the context of the conditions for prosecution of minors).
} 
than Spanish criminal law. The broad interpretation of the violent element by the requesting State would therefore have to be recognized by the executing State.

With regard to the allegation of embezzlement of public funds made by the Spanish judiciary, the examination of double criminality is dropped, because it can be attributed to the catalogue of corruption under Article 2(2) of the Framework Decision on the European arrest warrant-the opinion of the State to be requested is being determined. In assessing whether the circumstances of the offense are sufficiently described-Section 83a (1) Number 5 IRG - the only requirement is that the requesting State must plausibly state the requirements of the offense under Spanish law. It may therefore not be relevant whether a financial loss-as understood by the Germans-has occurred if under Spanish law even entering into the financial obligations for the referendum would be punishable.

\section{Judicial Control by the European Courts}

The Higher Regional Court of Schleswig-Holstein does not consider the criterion of double criminality to be fulfilled in view of the accusation of "rebellion" made by the Spanish judiciary and therefore rejects extradition detention as inadmissible from the outset. This is in accordance with the generally recognized benchmarks of the German law on mutual legal assistance, according to which an analogous conversion of the facts and a complete examination of the facts communicated by the requesting state must take place, as if the act had taken place on German territory. Accordingly, the offense of high treason presupposes a much more restrictive concept of violence than the Spanish offense of rebellion.

Nevertheless, the criterion of double criminality must be interpreted under European law, at least in the context of an extradition request based on a European arrest warrant. According to European Law, on the one hand, the analogous conversion of the facts oriented on the procedural concept of the offense and the subsequent hypothetical examination by the Court of Justice of the European Union is in principle supported. On the other hand, however, it appears that European law merely requires that the elements of the offense be identical in their content and not in their concrete application. In view of European law, the Higher Regional Court of Schleswig-Holstein-or the Supreme Court of Spain-should therefore make a request for a preliminary ruling by the Court of Justice of the European Union under Article 267 TFEU to clarify whether the principle of double criminality in the context of the conversion of facts into the criminal law of the executing State also includes the concrete examination of the interpretation of a criminal law by the executing State if this proves more restrictive than the interpretation of the requesting State. This is initially an unusual technique that breaks through German legal routines. The outcome may also be politically sensitive, especially as it becomes clear that Europe's criminal justice systems by no means follow common standards. If the political anxiety of the Carles Puigdemont case were to lead to the realization that the area of freedom, 
security, and justice lacks politically resistant legal principles, however, this would offer a welcome perspective for the development of European criminal law. 
